Inês Salva ${ }^{1}$, João Farela Neves' ${ }^{1}$, Maria João Brito ${ }^{1}$

1 Infectious Diseases' Unit, Pediatrics Department

Head of Department: Dr. Gonçalo Cordeiro Ferreira

Hospital de Dona Estefânia - CHLC, EPE, Lisbon

PORTUGAL

\title{
BACKGROUND
}

Norovirus is one of the genera of the Calicivirus family there are five Known genogroups (GG I through $\mathrm{V}$ ). ${ }^{1}$ It is one of the most common causes of gastoenteritis in both children and adults. 2 Neurologic complications such as febrile seizures are rare, although more frequent than observed with infections with other enteric virus, such as rotavirus.. ${ }^{1,2}$ Norovirus-associated encephalopathy is presumably rare, but has been reported twice.1,2
There is one reported case of encephalitis associated with positive PCR for norovirus in CSF. ${ }^{2}$

Other cases described presented with seizures or encephalopathy associated with negative CSF PCR for norovirus. There was a marked increase in CSF cytokynes, underlining the significance of inflammatory response versus direct nervous system invasion. ${ }^{1}$

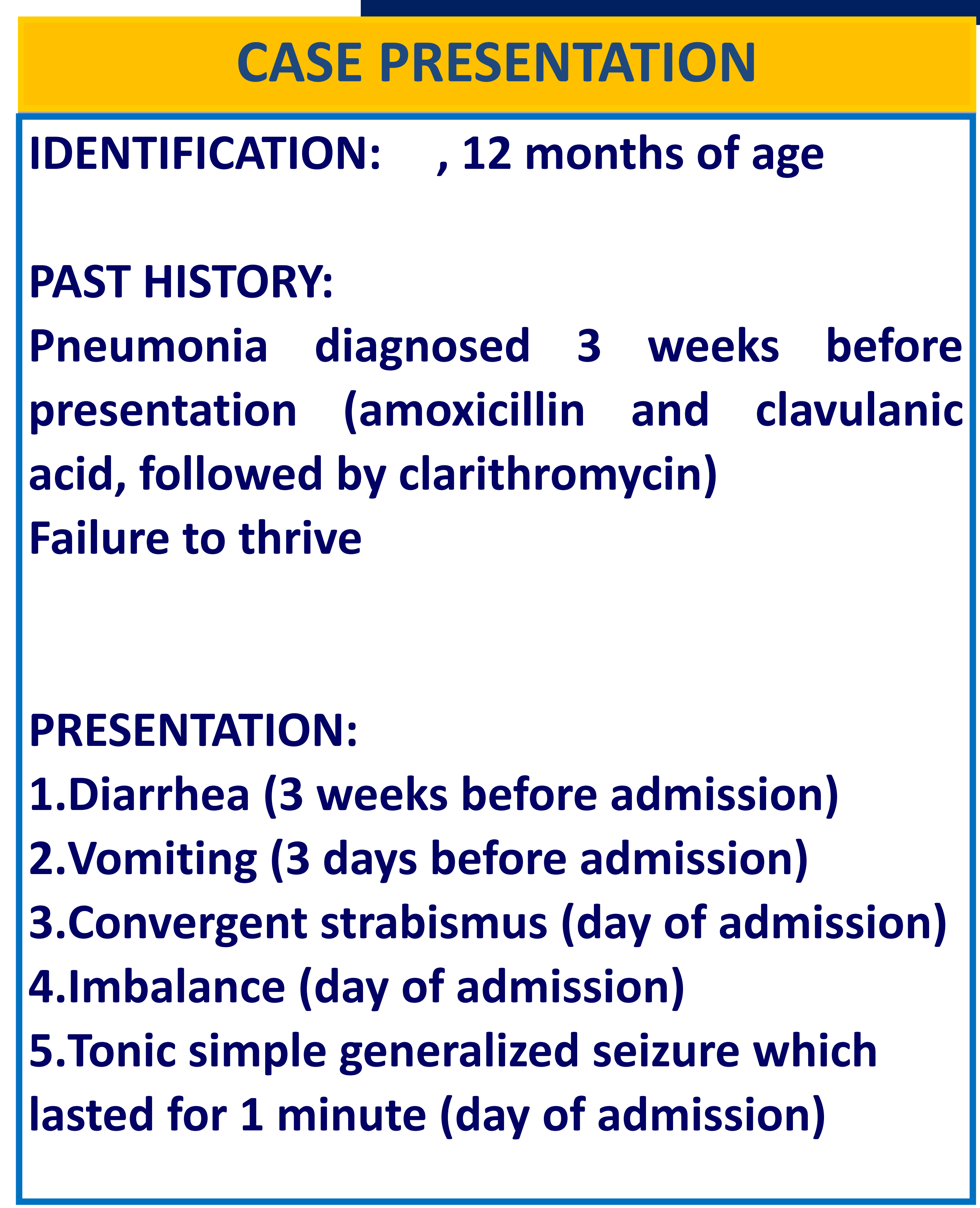

\begin{tabular}{|c|c|}
\hline \multicolumn{2}{|c|}{ LABORATORY TESTS } \\
\hline $\mathrm{Hb}$ & $10,9 \mathrm{~g} / \mathrm{dL}$ \\
\hline Leukocytes & $11.200 / \mu \mathrm{L}$ \\
\hline CRP & $0,11 \mathrm{mg} / \mathrm{dL}$ \\
\hline $\begin{array}{l}\text { Immunoelectrop } \\
\text { horesis }\end{array}$ & Negative \\
\hline CSF & $\begin{array}{c}5,6 \text { cells } / \mu \mathrm{L}, \\
100 \% \text { lymphocytes, glychorrachia } \\
80 \mathrm{mg} / \mathrm{Dl} \\
\text { (glycemia } 82 \mathrm{mg} / \mathrm{dL} \text { ) } \\
\text { proteinorrachia } 154 \mathrm{mg} / \mathrm{dL}\end{array}$ \\
\hline CSF IL-6 & $5,8 \mathrm{pg} / \mathrm{mL}$ (NORMAL) \\
\hline Rare paro: & $\begin{array}{c}\text { EEG } \\
\text { ysms located to the vertex }\end{array}$ \\
\hline
\end{tabular}

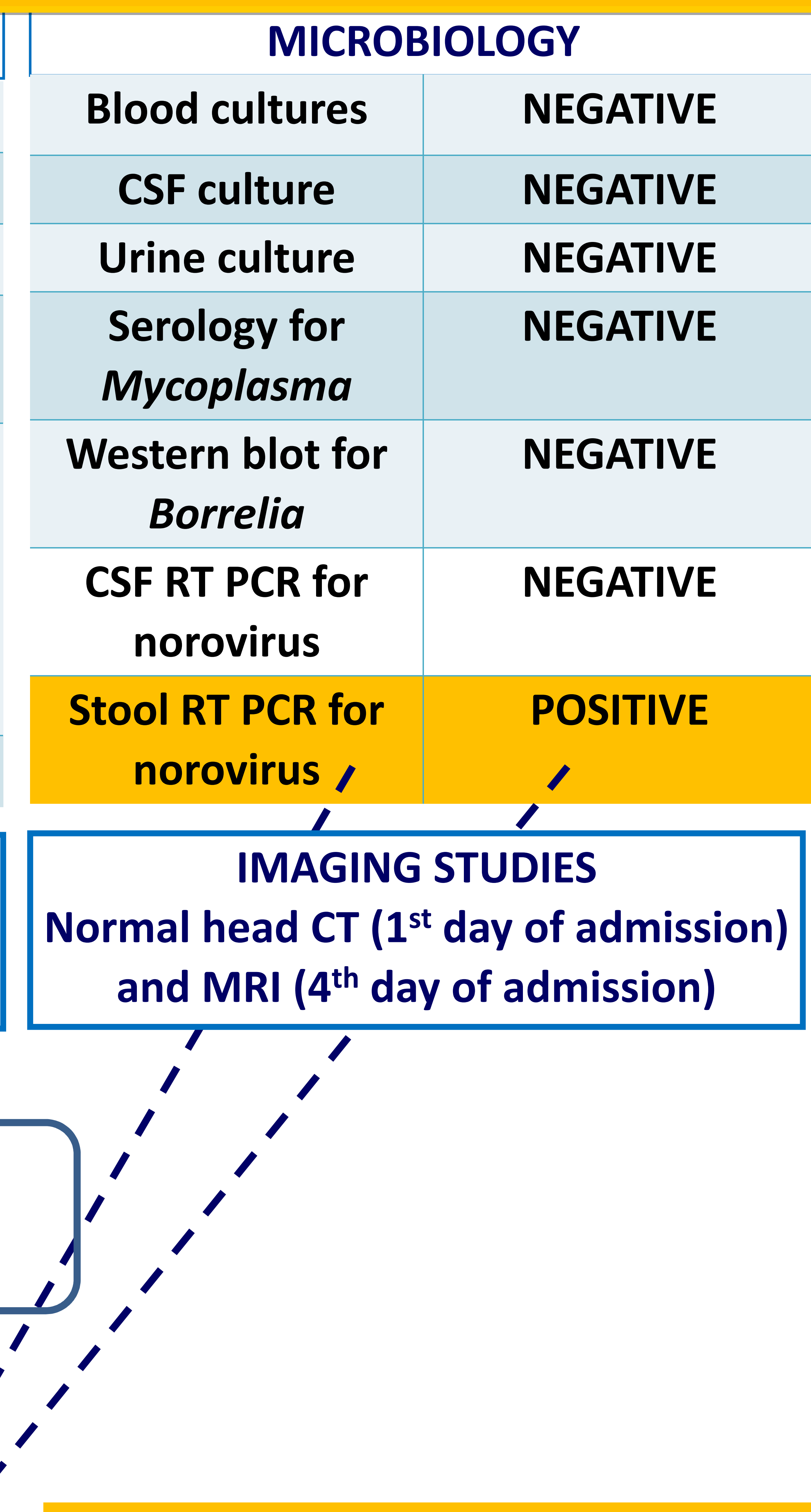

FOLLOW UP CONSULT

Normal immunoglobulin values for age, serologic response to anti-diphteria and anti-tetanus vaccines, lymphocyte NOROVIRUS-ASSOCIATED ENCEPHALOPATHY

\section{NEUROLOGY CONSULT}

Normal neurological outcome

population counts and proliferation assays

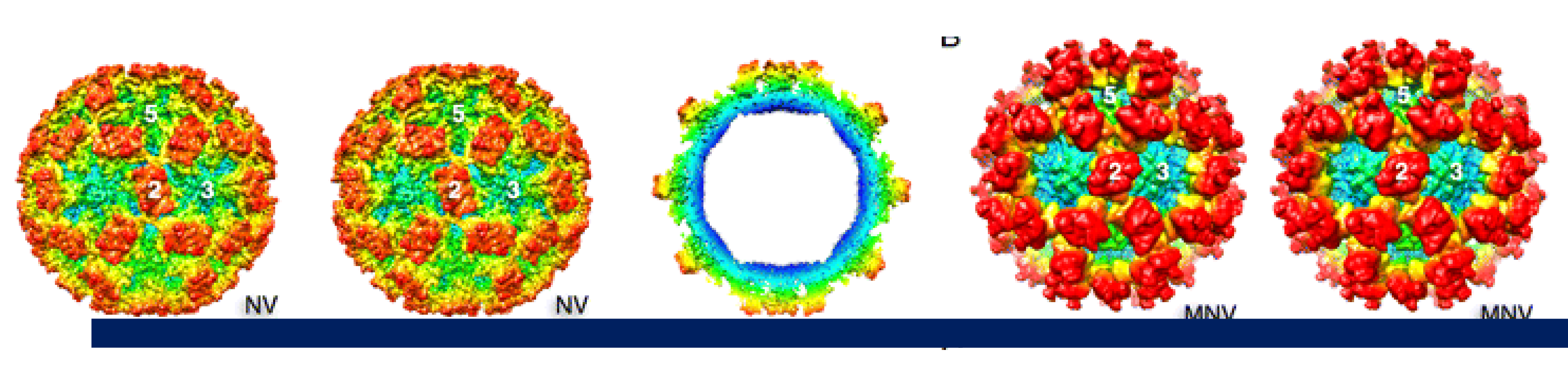

\section{COMENTS}

Here we present a case of a norovirus infection, associated with encephalopathy, with a normal neurological outcome and normal cytokyne levels in CSF, unlike previously described in some reports. ${ }^{2}$ Similarly to a previous report, norovirus was not found in CSF samples. ${ }^{2}$ Attending to the progressive emergence of this agent across the world, further studies are needed to clarify its pathogenicity and relevance in encephalopathy cases. ${ }^{1}$

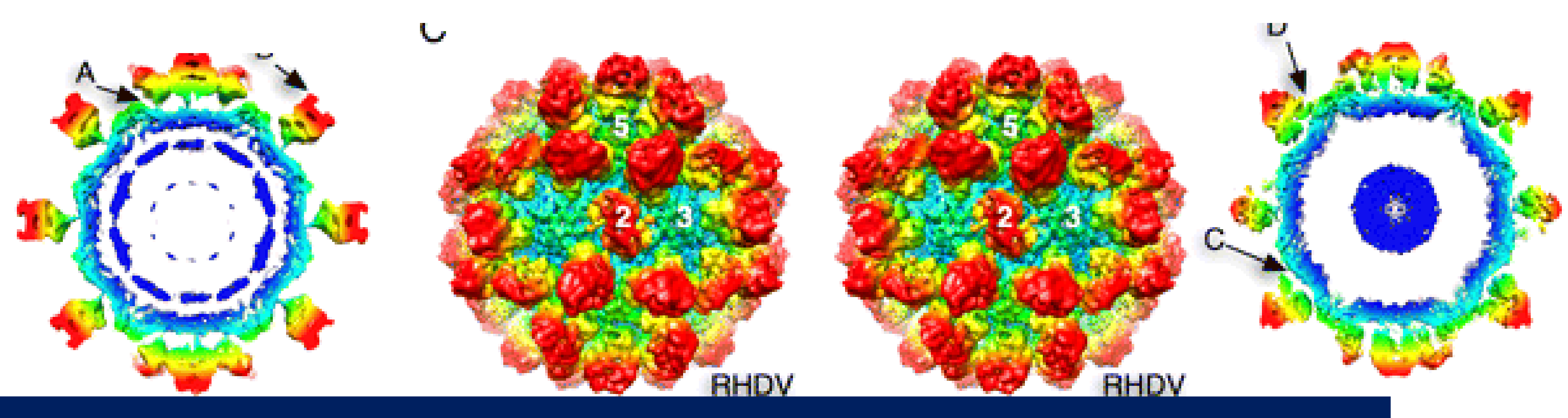

\section{REFERENCES}

1 - Ito S, Takeshita S, Nezu A, et al. Norovirus-associated encephalopathy. The Pediatric Infectious Diseases Journal. 2006, 25(7): 651-652;

2- Obinata K, Okumura A, Nakazawa T. Norovirus Encephalopathy in a Previously Healthy Child. The Pediatric Infectious Diseases Journal. 2010. 29(11): 1-2;

3 - Caul E. Viral gastroenterites: small round structured viruses, caliciviruses and astroviruses. Part II. The epidemiological perspective. J Clin Pathol. 1996. 49(12): 959-964. 